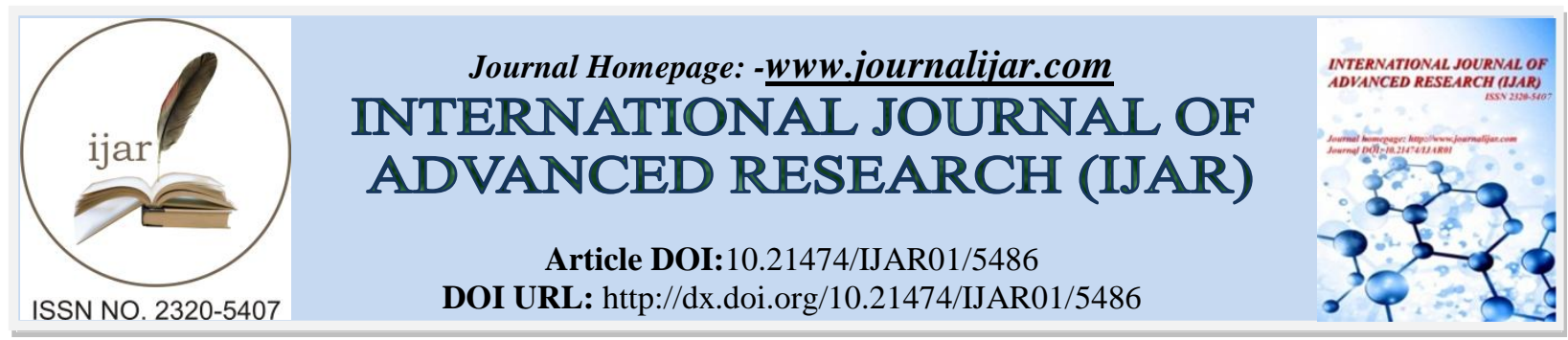

RESEARCH ARTICLE

\title{
INVOLVEMENT OF MITOGEN-ACTIVATED PROTEIN KINASE KINASE 6 IN BREAST TUMORIGENESIS.
}

\section{Rafia A. Baba ${ }^{1}$, Umar Mushtaq ${ }^{2}$, Arif A. Parray ${ }^{2}$, Deeba Kirmani ${ }^{2}$, Lateef A. Wani ${ }^{3}$ and Firdous A. Khanday ${ }^{2}$.}

1. Sher-i-Kashmir Institute of Medical Sciences, Soura, Srinagar, 190011, Srinagar, Jammu and Kashmir, India.

2. Department of Biotechnology, University of Kashmir, 190006, Srinagar, Jammu and Kashmir, India.

3. Department of Surgery, Shri Maharaja Hari Singh Hospital, 190011, Srinagar, Jammu and Kashmir, India.

\section{Manuscript Info}

Manuscript History

Received: 21 July 2017

Final Accepted: 23 August 2017

Published: September 2017

Key words:-

Breast cancer, Carcinoma,

Immunoblotting, MKK6, Protein

expression.

\section{Abstract}

MKK6 expression analysis has been reported in various primary tumors, like esophagus, stomach, colon and prostate cancers but its significance in primary breast tumor patients remains unclear. We investigated the expression of MKK6 in cancer tissues through immunoblotting and immunofluorescence techniques in 25 resected cases of human breast carcinomas. Increased MKK6 protein expression was observed in 56\% (14/25) of breast cancer cases. These results indicate that the upregulated expression of MKK6 in cancer tissues has significant role in tumor progression and the clinical prognosis of patients with primary breast carcinoma.

Copy Right, IJAR, 2017,. All rights reserved.

\section{Introduction:-}

Breast cancer is one of the most common cancers with more than 1.3 million cases and 0.45 million deaths each year worldwide [1]. It is the number one cancer amongst females accounting for $5.59 \%$ of total cancers in females of Kashmir valley only [2]. Breast cancer development involves progression through chain of intermediate processes, which starts with ductal hyper-proliferation, followed by subsequent progression to carcinoma in situ, invasive carcinoma, and finally into metastatic disease [3]. Studies have shown that metastasis is a series of diverse events, generally known as a metastatic cascade. These steps include fleeing of malignant cells from the site of primary tumor, propagation and shifting to a discontinuous secondary site(s), and lastly, the survival and growth into clinically detectable metastases, a process termed metastatic colonization [4]. In order to significantly augment our understanding of the metastatic process and to identify the specific targets for cancer therapy we need to single out the proteins and signaling pathways necessary for regulation of metastasis. In various cancers many proteins show differential expression and regulation [5-7]. One such protein is mitogen-activated protein kinase 6 (which from now onwards will be referred to as MKK6). MKK6 belongs to the mitogen-activated protein (MAP) kinase super family and has a role in both apoptosis [8,9] as well as proliferation [10]. MKK6 has been implicated in regulating tumorigenesis. MKK6 has been shown to play contradictory roles in suppressing metastatic colonization in human ovarian carcinoma [11] on other hand it has been shown to be up-regulated in prostate cancers [12]. As of now, very little is known about the regulation of expression of MKK6 in the cell [13]. MKK6 activates downstream all the isoforms of p38 MAPK [14]. P38 $\alpha$ has been implicated in regulating cancer progression, by regulating invasion, inflammation and angiogenesis which are key oncogenic steps in tumorogenesis[15-17]. 
In our previous study we have reported a dramatic up-regulation of the MKK6 in esophageal, stomach and colon cancers [7], and as already mentioned an upregulation has also been reported in prostatic carcinomas [5]. The expression pattern of MKK6 has never been systematically evaluated in breast cancer and the specific role of MKK6 in breast cancer progression is incompletely understood. Thus we focused this study on checking the expression pattern of MKK6 protein in human breast cancerous tissues that might help in providing an attractive target for future biomarkers against the said disease.

\section{Materials and Methods:-}

Human tissue procurement:

Twenty five patients ( 1 male, 24 females) examined and treated at Shri Maharaja Hari Singh Hospital (Srinagar City, India) for breast carcinomas were evaluated for this study. The study was approved by the Ethics Committee for Clinical Research of the hospital. Primary tumors and adjacent non-neoplastic breast tissue were obtained at the time of surgery, evaluated by a pathologist, and used for the studies.

Chemicals \&Antibodies:

Chemicals used for carrying out protein extraction and western blotting were of analytical grade and were purchased from SIGMA-ALDRICH (USA). From Genei laboratories (India), we purchased Bradford micro-protein estimation kit. PVDF membrane was purchased from WHATMANN (Germany). All electrophoresis reagents were obtained from SIGMA-ALDRICH (USA), Thermo Scientific (USA), Qualigens (India) and Spectrochem (India), ECL solutions for protein detection were obtained from Thermo Scientific (USA). Rabbit Polyclonal MKK6 antibody was purchased from Cell Signaling Technology Inc., phospho-MKK6 was purchased from ABCAM, anti-rabbit HRP-conjugated Secondary Antibody and Anti-Rabbit igg-FITC antibody was purchased from SIGMA-ALDRICH (USA). Anti-Vinculin antibody was purchased from MILLIPORE.

\section{Protein extraction and estimation:}

Protein extraction and estimation were carried out as done previously [18].

Immunoblotting:

$35 \mu \mathrm{g}$ of protein extract, preheated at $100^{\circ} \mathrm{C}$ for $3 \mathrm{~min}$ in reducing sample buffer containing $50 \mathrm{~mm}$ TrisCl (ph 6.8), $2 \%$ SDS, $10 \%$ glycerol, $0.1 \%$ bromophenol blue, $100 \mathrm{~mm} \beta$-mercaptoethanol, were run on $10 \%$ SDSpolyacrylamide gel and proteins were transferred onto PVDF membrane (Whatmann). Membranes were then blocked with 5\% BSA in TBS followed by an overnight incubation with primary antibodies (1:1000 dilution of antiMKK6 in 5\% BSA in TBS, 1:1000 dilution of anti-VinculinAb in 5\% skimmed milk in TBS) at $4^{\circ} \mathrm{C}$. After washing with TBS containing $0.1 \%$ Tween-20, the membranes was incubated with horseradish peroxidase-conjugated secondary antibody (1:7000) dilution in 5\% skimmed milk in TBS) for 2 hours at room temperature. Protein bands were detected with chemiluminescence as done previously [18]. Three independent experiments were done to confirm all the results.

\section{Immunofluorescence:}

The experiments were carried out as done previously [18] and the photographs of the sections were taken by a camera mounted on a Leica fluorescence microscope.

\section{Results:-}

The expression of MKK6 (molecular weight 38kda) was examined in 25 breast carcinomas and the adjacent normal breast tissues by Western blotting and Immuno-fluorescence using anti-rabbit MKK6 polyclonal antibodies. Out of 25 patients, 14 patients (56\%) showed upregulation of MKK6 protein. The age of the patients ranged from 20-70 years. The majority of the cases were in the age group of 40-60 years [Table - 1]. In cancerous breast tissue the expression of MKK6 was found to be considerably up-regulated as compared to the normal breast tissue (Figure 1A). In all the experiments, blots were stripped and treated with anti-Vinculin antibody used as loading control which showed equal expression (lower panel in figure1a). Immunostaining was also carried out alternatively in human tissues and the expression of MKK6 was found to be significantly higher in terms of recorded fluorescence signal as compared to the surrounding normal breast tissue (Figure 1B). Western blot analysis using phospho-MKK6 antibody was also carried out to check for the activation of MKK6 (phosphorylated form) and the obtained results indicated an increase in the level of activated MKK6 in cancerous tissue as compared to normal breast tissue (Figure $1 \mathrm{C})$. 


\section{Discussion:-}

In the present study, we carried out Immunoblotting and Immunofluorescence of human breast tissue specimens to detect the protein expression of MKK6 and we have shown that clinical specimens of tumor tissues had increased expression of MKK6, but not in adjacent normal breast tissues. To our knowledge, this is the first study to detect protein expression of MKK6 protein in breast carcinoma. We also report that MKK6 expression might be a useful prognostic marker for the breast carcinoma patient survival. Using Western Blot analysis and Immunofluorescence techniques increased MKK6 protein expression was observed in 56\% (14/25) of breast cancer cases. The reported over expression may be due to an increased transcription of the related genes or due to posttranscriptional modifications. In conclusion, our results suggest that increased MKK6 expression might play an important role in progression of breast tumorigenesis and may have diagnostic and therapeutic consequences.

Conflict of interest: The authors declare no conflict of interest.

Ethical clearance: The study was approved by the Human Ethics Review Committee of SMHS Hospital and proper consent was taken from the patients.

(A)
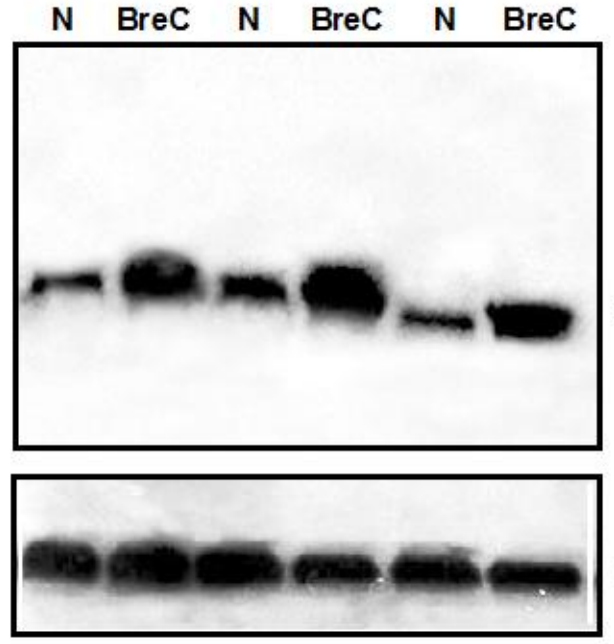

$\longrightarrow$ Vinculin

(C)

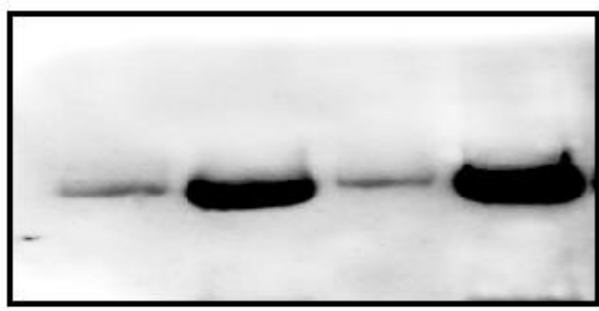

(117kDa)

MKK6

$(38 \mathrm{kDa})$

(B)
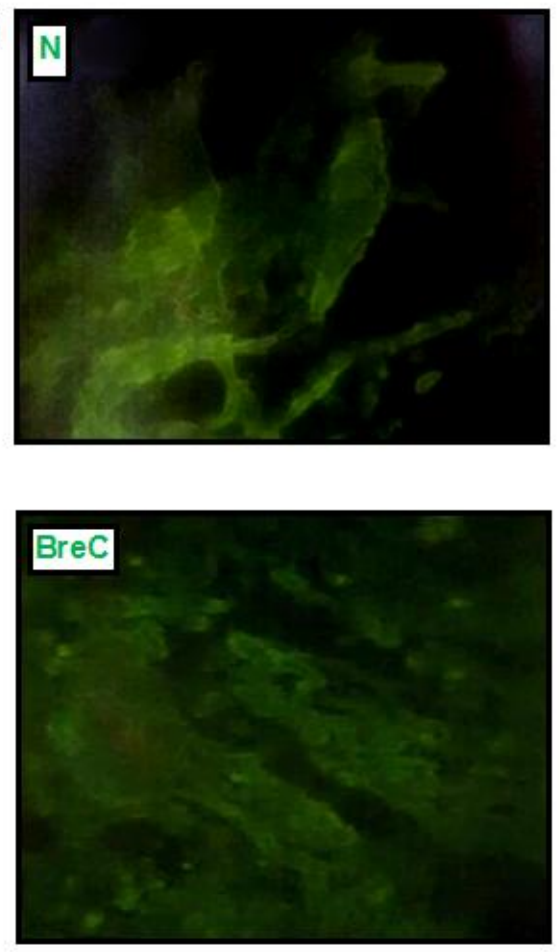

Figure 1:-Up-regulation in the expression of MKK6 protein A: Representative Western blot showing the increase in the expression of MKK6 in Breast tissues (Cancerous Vs. Normal) B: Immunofluorescence staining showing upregulated expression of MKK6 protein in Breast tissues (Cancerous Vs. Normal) C: Representative Western blot showing the activation of MKK6 in Breast tissues (Cancerous Vs. Normal) *The analysis was carried out on different individuals each time.

Table 1:-

\begin{tabular}{|l|l|l|l|l|l|l|l|}
\hline $\begin{array}{l}\text { Age } \\
\text { Group }\end{array}$ & $\begin{array}{l}\text { No. } \\
\text { Of } \\
\text { Canc } \\
\text { er } \\
\text { Patie } \\
\text { nts }\end{array}$ & $\begin{array}{l}\text { Healt } \\
\text { Cont } \\
\text { rols }\end{array}$ & $\begin{array}{l}\text { Upregulated MKK6 in } \\
\text { Cancer Patients }\end{array}$ & $\begin{array}{l}\text { Upregul } \\
\text { ated } \\
\text { MKK6 } \\
\text { in } \\
\text { Healthy } \\
\text { Control } \\
\text { s\# }\end{array}$ & & & \multicolumn{2}{|l|}{ Strength of association } \\
\hline & & & & & $P$ & Odds ratio & Sensitivi \\
\hline
\end{tabular}




\begin{tabular}{|c|c|c|c|c|c|c|c|c|}
\hline & & & & & value & $(95 \% C I)$ & $\begin{array}{l}y \\
(95 \% \\
C I)\end{array}$ & $\begin{array}{l}y \\
(95 \% \\
C I)\end{array}$ \\
\hline $20-30$ & 1 & 1 & Nil & 0 & 1 & $\begin{array}{l}1 \\
(0.011 \text { to } \\
92.52)\end{array}$ & $\begin{array}{l}0 \\
(0.0 \quad \text { to } \\
0.98)\end{array}$ & $\begin{array}{l}1 \\
(0.02 \text { to } \\
1.0)\end{array}$ \\
\hline $30-40$ & 2 & 1 & 1 & 0 & 1 & $\begin{array}{l}3 \\
(0.060 \text { to } \\
151.3)\end{array}$ & $\begin{array}{ll}0.5 & \\
(0.01 \quad \text { to } \\
0.99)\end{array}$ & $\begin{array}{l}1 \\
(0.020 \text { to } \\
1.0)\end{array}$ \\
\hline $40-50$ & 7 & 3 & 3 & 0 & 0.475 & $\begin{array}{l}5.44 \\
(0.20 \\
144.2)\end{array}$ to & $\begin{array}{l}0.42 \\
(0.09 \text { to } \\
0.81)\end{array}$ & $\begin{array}{l}1 \\
(0.29 \text { to } \\
1.0)\end{array}$ \\
\hline $50-60$ & 12 & 5 & 8 & 0 & $\begin{array}{l}0.0294 \\
*\end{array}$ & $\begin{array}{l}20.78 \\
(0.92 \\
467.3)\end{array}$ to & $\begin{array}{ll}0.66 & \\
(0.35 & \text { to } \\
0.90)\end{array}$ & $\begin{array}{l}1 \\
(0.48 \text { to } \\
1.0)\end{array}$ \\
\hline $60-70$ & 3 & 2 & 2 & 0 & 0.4 & $\begin{array}{ll}8.33 & \\
(0.22 & \text { to } \\
320.7) & \\
\end{array}$ & $\begin{array}{ll}0.67 & \\
(0.09 & \text { to } \\
0.99) & \\
\end{array}$ & $\begin{array}{l}1 \\
(0.16 \text { to } \\
1.0)\end{array}$ \\
\hline Total & 25 & 12 & 14 & 0 & $\begin{array}{l}\mathbf{0 . 0 0 0 9} \\
* * *\end{array}$ & $\begin{array}{ll}31.52 & \\
(1.68 & \text { to } \\
591.2) & \\
\end{array}$ & $\begin{array}{ll}0.56 & \\
(0.35 & \text { to } \\
0.75) & \\
\end{array}$ & $\begin{array}{ll}1 \\
(0.73 \text { to } \\
1.0)\end{array}$ \\
\hline
\end{tabular}

${ }^{*} p<0.5$ (significant); $* * p<0.01$ (most significant); $* * * p<0.001$ (highly significant). Data were analyzed using Fisher's exact test across each age - group.

\# Vs. Adjacent normal of Cancer Tissue

\section{Acknowledgment:-}

This work was supported by Department of Biotechnology, Ministry of Science \& Technology, Govt. Of India, under the scheme/subhead Non-infectious diseases of humans No.BT/PR7420/MED/30/923/2012.

\section{References:-}

1. Comprehensive molecular portraits of human breast tumours (2012). Nature 490 (7418):61-70

2. Rumana, M., Khan, A., Besina, S., Seema, A., Shah, B., Nayi, K., Ahmad, R., Qazi, S. (2011): Cancer profile in Kashmir valley an institutional experience. JK-Practitioner., 16 (1-2):50-54

3. Polyak, K. (2007): Breast cancer: origins and evolution. J Clin Invest., 117 (11):3155-3163

4. Fidler, I. J., Gersten, D. M., Hart, I. R. (1978): The biology of cancer invasion and metastasis. Adv Cancer Res., 28:149-250

5. Bhat, H. F., Baba, R. A., Bashir, M., Saeed, S., Kirmani, D., Wani, M. M., Wani, N. A., Wani, K. A., Khanday, F. A. (2011): Alpha-1-syntrophin protein is differentially expressed in human cancers. Biomarkers., 16 (1):3136

6. Mushtaq, U., Baba, R., Parray, A. A., Bhat, H. F., Saleem, S., Manzoor, U., Kuchay, S., Wani, L., Khanday, F. A. (2014): Mitogen Activated Protein Kinase Kinase-4 Upregulation is a Frequent Event in Human Stomach and Colon Cancers. JEM., 8:10

7. Parray, A. A., Baba, R.A., Bhat, H. F., Wani, L., Mokhdomi, T. A., Mushtaq, U., Bhat, S. S., Kirmani, D., Kuchay, S., Wani, M. M., Khanday, F.A. (2014): MKK6 is upregulated in human esophageal, stomach, and colon cancers. Cancer Invest., 32 (8):416-422

8. Cardone, M. H., Salvesen, G. S., Widmann, C., Johnson, G., Frisch, S. M. (1997): The regulation of anoikis: MEKK-1 activation requires cleavage by caspases. Cell., 90 (2):315-323

9. Toyoshima, F., Moriguchi, T., Nishida, E. (1997): Fas induces cytoplasmic apoptotic responses and activation of the MKK7-JNK/SAPK and MKK6-p38 pathways independent of CPP32-like proteases. J Cell Biol., 139 (4):1005-1015

10. Zechner, D., Thuerauf, D. J., Hanford, D. S., mcdonough, P. M., Glembotski, C. C. (1997): A role for the p38 mitogen-activated protein kinase pathway in myocardial cell growth, sarcomeric organization, and cardiacspecific gene expression. J Cell Biol., 139 (1):115-127 
11. Hickson, J. A., Huo, D., Vander Griend, D. J., Lin, A., Rinker-Schaeffer, C. W., Yamada, S.D. (2006): The p38 kinases MKK4 and MKK6 suppress metastatic colonization in human ovarian carcinoma. Cancer Res., 66 (4):2264-2270

12. Lotan, T. L., Lyon, M., Huo, D., Taxy, JB., Brendler, C., Foster, B. A, Stadler, W., Rinker-Schaeffer, C. W. (2007): Up-regulation of MKK4, MKK6 and MKK7 during prostate cancer progression: an important role for SAPK signalling in prostatic neoplasia. J Pathol., 212 (4):386-394

13. Ambrosino, C., Mace, G., Galban, S., Fritsch, C., Vintersten, K., Black, E., Gorospe, M., Nebreda, A. R. (2003): Negative feedback regulation of MKK6 mrna stability by p38alpha mitogen-activated protein kinase. Mol Cell Biol., 23 (1):370-381

14. Chang, L., Karin, M. (2001): Mammalian MAP kinase signalling cascades. Nature., 410 (6824):37-40

15. Bulavin, D. V., Fornace, A. J. (2004): p38 MAP kinase's emerging role as a tumor suppressor. Adv Cancer., Res 92:95-118

16. Dolado, I., Nebreda, A. R. (2007): Regulation of tumorigenesis by p38 $\alpha$ MAP kinase. In: Stress-Activated Protein Kinases. Springer., 99-128

17. Hui, L., Bakiri, L., Stepniak, E., Wagner, E. F. (2007): p38alpha: a suppressor of cell proliferation and tumorigenesis. Cell Cycle., 6 (20):2429-2433

18. Baba, R. A., Bhat, H. F., Wani, L. A., Bashir, M., Wani, M. M., Qadri, S. K., Khanday, F. A. (2012): E3B1/ABI-1 isoforms are down-regulated in cancers of human gastrointestinal tract. Dis Markers., 32 (4):273279 